\title{
Ethnotaxonomy of Sharks by Expert Fishers from South Bahia, Brazil: Implications for Fisheries Management and Conservation
}

\author{
Márcio Luiz Vargas Barbosa Filho ${ }^{1 ; 2 *}$; Milena Ramires ${ }^{3}$; José da Silva Mourão \\ 4 [ ; Ricardo de Souza Rosa ${ }^{5}{ }^{(1)}$; Rômulo Romeu da Nóbrega Alves ${ }^{4}$ (D) and \\ Eraldo Medeiros Costa-Neto 6 (i)
}

\begin{abstract}
Historically, Brazilian fisheries management has not considered the knowledge of fish taxonomy from within fishing communities. This study points out processes of recognition, classification and nomenclature of sharks achieved by fishermen from South Bahia, Brazil. Data were obtained through semistructured interviews visually stimulated by exhibiting images of 30 species of elasmobranch fishes. Regionally, elasmobranch species are inserted into the folk taxon called "leather fishes" and in a category known as "cação" (shark) family. In addition to hierarchical classification, the fishermen organize shark species by adopting an ethnodimorphic and sequential model based on ethnoontogeny. Ethnodiagnostic characteristics are mainly related to the morphology, ecology and even physiology of a species. A total of 144 epithets is recorded, with a mean value of 4.8 ethnospecies for each scientific correspondent. Richness of vernacular names impedes species-specific information gathering regarding shark landings if fisher knowledge is not considered and applied in the improvement of fisheries data. Thus, this study encourages the employment of fishermen as parataxonomists in order to assist in the identification of sharks to specific levels. This study further emphasizes the potential of using ethnotaxonomic knowledge of fishing communities in initiatives related to participative management of shark fisheries in developing countries.
\end{abstract}

Keywords: Elasmobranch Fishes; Fisheries Statistics; Folk Taxonomy; Parataxonomists.

1 Departamento de Ciências Biológicas, Programa de Pós-graduação em Zoologia, Universidade Estadual de Santa Cruz, Salobrinho, 45662-900 Ilhéus, BA, Brazil.

2 Current affiliation: Programa de Pós-graduação em Etnobiologia e Conservação da Natureza, Universidade Federal Rural de Pernambuco, Campus Dois Irmãos, 52171-900 Recife, PE, Brazil.

3 Laboratório de Ecologia Humana, Universidade Santa Cecília, Rua Oswaldo Cruz, 277, Boqueirão, 11045-907 Santos, SP, Brazil. 4 Departamento de Biologia, Universidade Estadual da Paraíba, Rua Baraúnas, 351, Bairro Universitário, $58429-500$ Campina Grande-PB, Brazil.

5 Laboratório de Ictiologia, Departamento de Sistemática e Ecologia - CCEN, Universidade Federal da Paraíba, Campus Universitário I, Cidade Universitária s/n, 58051-900 João Pessoa, PB, Brazil.

6 Departamento de Ciências Biológicas, Universidade Estadual de Feira de Santana, Avenida Transnordestina S/N, Novo Horizonte, 44036-900 Feira de Santana, BA, Brazil.

* Corresponding author $\bowtie$. E-mail address: MLVBF (titobiomar@hotmail.com), MR (milena.ramires@hotmail.com), JSM (tramataia@gmail.com), RSR (rsrosa@dse.ufpb.br), RRNA (romulo_nobrega@yahoo.com.br), EMCN (eraldont@hotmail.com) 


\section{SIGNIFICANCE STATEMENT}

The manuscript describes the ethnotaxonomic knowledge of traditional fishermen of southern Bahia with respect to sharks. The study area is part of a region considered a hotspot of elasmobranch fish biodiversity. The main contribution of the manuscript is to demonstrate the ability of traditional fishermen to identify shark species in catches, which represents a great challenge even for scientists. In Brazil, as in other developing countries, fishing landing statistics usually do not report shark catches at the specific level, a situation that limits the potential for their proper management and conservation. The use of fishermen's knowledge can facilitate the identification of these fish at a specific level at landings. In this way, we emphasize the potential of including fishers as parataxonomists in fishery landing systems, a fact that, in addition to generating work and income for them, may contribute to strengthen partnership relationships with scientists.

\section{INTRODUCTION}

Human beings classify things into groups by their similarities and differences (Raven et al. 1971; Mishler and Donoghue 1982). Taxonomies are a result of the scientific classification of organisms. Folk taxonomy is a system of the vernacular nomenclature that diverges from scientific taxonomy as it reflects the experience, goals and values of people. Moreover, it works as a convenient tool in obtaining information about the natural world, displaying ways in which people observe the environmental components, and their perception and comprehension of nature as a whole (Ellen 1993; Atran 1998; Gould 2001; Beaudreau et al. 2011). Folk taxonomy is considered a hierarchical metaphor that includes notions associated to category, level and contrast, and additionally serves as a guide to decode the natural world and involves the mental processes when compared to those of modern Science (Maffi 1999; Medin and Atran 2004).

Naming of live animals in folk taxonomy is a process that confers contextual significance to objective continuities and discontinuities in nature. It is essentially similar in every language and it is based on a small number of nomenclatural principles (Berlim et al. 1973). Atran (1990) states that knowing the vocabulary of a certain local population is the first step for accessing information related to a variety of cognitive domains that comprise the human mind. It also represents an indirect approach to the formation and diffusion of concepts related to the studied context (Atran 1990). Conklin (1962) was one of the pioneers to prove the existence of similar taxonomic structures among many traditional human groups, opening means to investigate the existence of universal biological taxonomic structures.

Berlin (1973) established three main areas of study in folk taxonomy: classification (related to principles of organization of organisms), nomenclature (related to principles of linguistics employed for naming folk classes), and identification (related to the study of relationships between characteristics of individuals and classification). According to this author, ethnobiological classifications consider the principle of universality between different cultures in which there are regularities for the classification and nomenclature of plants and animals among traditional populations. Some ethnobiological principles of classification and nomenclature were suggested by Berlin (1973) to identify similarities among cognitive systems in various societies. Berlin (1992) established six hierarchical categories (king, life form, intermediate, generic, specific and varietal), according to the existence of a basic plan of nature in which human beings of any area of the world would be similarly affected by the remarkable aspects of the morphology of plants and animals.

Studies of folk taxonomy in fishing communities began during the 1960s (e.g. Morril 1967). Freire and Carvalho-Filho (2009) pointed out that richness of epithets employed for naming reef fishes is a result of the Brazilian cultural diversity, with a mean value of 7.2 names per species when examining vernacular names of 547 local species. Miscegenation between indigenous, African and white populations assigned ethnographic and linguistic richness to the fisheries culture in Bahia State, Brazil (Ott 1944). The Brazilian Federal Government considers the south region of Bahia State as a priority area for conservation of coastal and marine biodiversity (MMA 2002), as it bears the most extensive coral formation in the South Atlantic Ocean and it provides habitat to almost 300 fish species (Dutra et al. 2005). Previero et al. (2013) pinpointed this region as a hotspot for common fish names and designated it as a Tower of Babel to highlight the challenges of fishery monitoring in the region. These authors noticed that the category of the generic common name "cação" (shark) contained the highest number of specific epithets. Phenotypic similarity is intrinsic within 500 valid species of sharks (Compagno 2005), which disrupts worldwide monitoring of fish landings to species level. Estimation of population sizes of landed species is challenging. This is especially evident in the artisanal fisheries where landing logbooks or observer sheets are not available aboard fishing vessels. In Brazil, for instance, shark landing data are provided at the categories of class and order in more than $90 \%$ of the available monitoring landing systems (Fischer et al. 2012), even though 
the country is considered a shark biodiversity hotspot (Lucifora et al. 2011). Thus, fishery scientists and decision-making specialists have the challenge of suggesting alternatives to reverse this obstacle for management and conservation purposes of the group along the Brazilian coast.

Informalities and non-existence of historical series of capture data from small-scale fishery landings make it unfeasible to accomplish satisfactory inferences about the population dynamics of species (Castello et al. 2007). These inferences are essential to support initiatives related to fisheries management (Sparre and Venema 1997). It is necessary to access as many sources of information as possible, including those provided by fishing communities (Costello et al. 2012). These communities bear valuable knowledge about the ecology and biology of exploited resources and they may collaborate directly to the development of public actions for fisheries management (Yaeger et al. 2017). Furthermore, their participation in decision-making processes as social actors contributes to the political and social empowerment of the fishing community in the engagement of the human and labor rights, and improvement of life quality. Even though ethnobiological knowledge of fishing communities has not been historically considered in the development of actions for fisheries management, several studies on ethnobiological knowledge of shark species have been conducted in recent years (e.g. Bizzarro et al. 2009; Powers et al. 2013; Barbosa-Filho et al. 2014; Barbosa-Filho et al. 2017; Humber et al., 2017). This study aimed to detect how recognition, classification and nomenclature of shark species are undertaken in the fishing communities from Bahia State, Brazil, in order to contribute to the management and conservation of elasmobranch fishes. The results indicate the potential to include ethnotaxonomic knowledge in the development of initiatives for sustainable fisheries of sharks on a broad scale.

\section{MATERIAL AND METHODS}

\section{Sampling sites}

Data collection was carried out in the municipalities of Ilhéus, Una and Canavieiras in Bahia State, which together comprise $164 \mathrm{~km}$ of the Brazilian coast. In this region, the continental shelf varies in extension, becoming broader in a north-south direction (Nascimento et al. 2007). Two main areas are defined here: the first area is situated North of Ilhéus municipality with its continental shelf comprising $11 \mathrm{~km}$ width; a second area located South of Ilhéus has the continental shelf width of $100 \mathrm{~km}$ near the Royal Charlotte Bank off the Canavieiras municipality (Nascimento et al. 2007). This variation facilitates the capture of many coastal, oceanic and shelf-associated shark species by the local fishermen.

There are at least 20 fishing communities in the study area. Ponta do Ramo, Mamoã beach, Ponta da Tulha, Barra do Itaípe, São Miguel, Prainha, Pontal, Cururupe, Olivença, Jairí beach and Acuípe communities are situated in Ilhéus municipality. Lençóis beach, Esperança farm, Pedras de Una, and Comandatuba Island are located in Una municipality. Puxim da Praia, Barra Velha, downtown area, Porto do Areal and Atalaia village belong to Canavieiras municipality. Fishermen with experience in shark fisheries are found in 13 fishing communities as illustrated in Figure 1 .

Semi-structured interviews were conducted during February and October 2012 using a standardized survey questionnaire, according to Albuquerque et al. (2014). A total of 65 fishermen were interviewed, corresponding to 38 individuals in Canavieiras, two in Una, and 25 in Ilhéus. All interviews were recorded using a digital audio recorder, totaling 70.4 hours. Ethnobiological and ethnotaxonomic knowledge of shark species and ethnoecology of local fisheries were covered in the interviews.

Sampling is according to the checklist-interview method of Medeiros et al. (2014), showing pictures (Additional files) of target species to stimulate interviews. Printed images of 30 shark species were numbered in order to organize them sequentially according to phenotypic similarities and facilitate comparisons. The following questions were asked for each species:

1. Is this fish a shark?

2. What is the name of this species?

3. Why does the species have this name?

Images illustrating the main diagnostic features of a species were preferably chosen when possible. Correspondence of common and vernacular names employed by the fishing community was verified with those available in the related literature (e.g. Brandão 1964; Figueiredo 1977; Queiróz and Rebouças 1995; Lessa and Nóbrega, 2000; Szpilman 2004; Freire and Carvalho-Filho 2009).

Images were taken from Fishbase (Froese and Pauly, 2006) and other resources that allow unlimited usage of intellectual property for scientific proposes. Preliminary interviews included 21 shark species indicated in Queiróz and Rebouças (1995) as occurring along Bahia coast. Four species additionally recorded in this area by Olavo et al. (2005) and Nunan and Senna (2007) were also included in the analysis. Three species of stingrays (Order Myliobatiformes) recognized in the study area as types of "cações" (sharks) were also included. Two species of sharks (Galeorhinus galeus (Linnaeus, 1758) and Carcharias taurus 


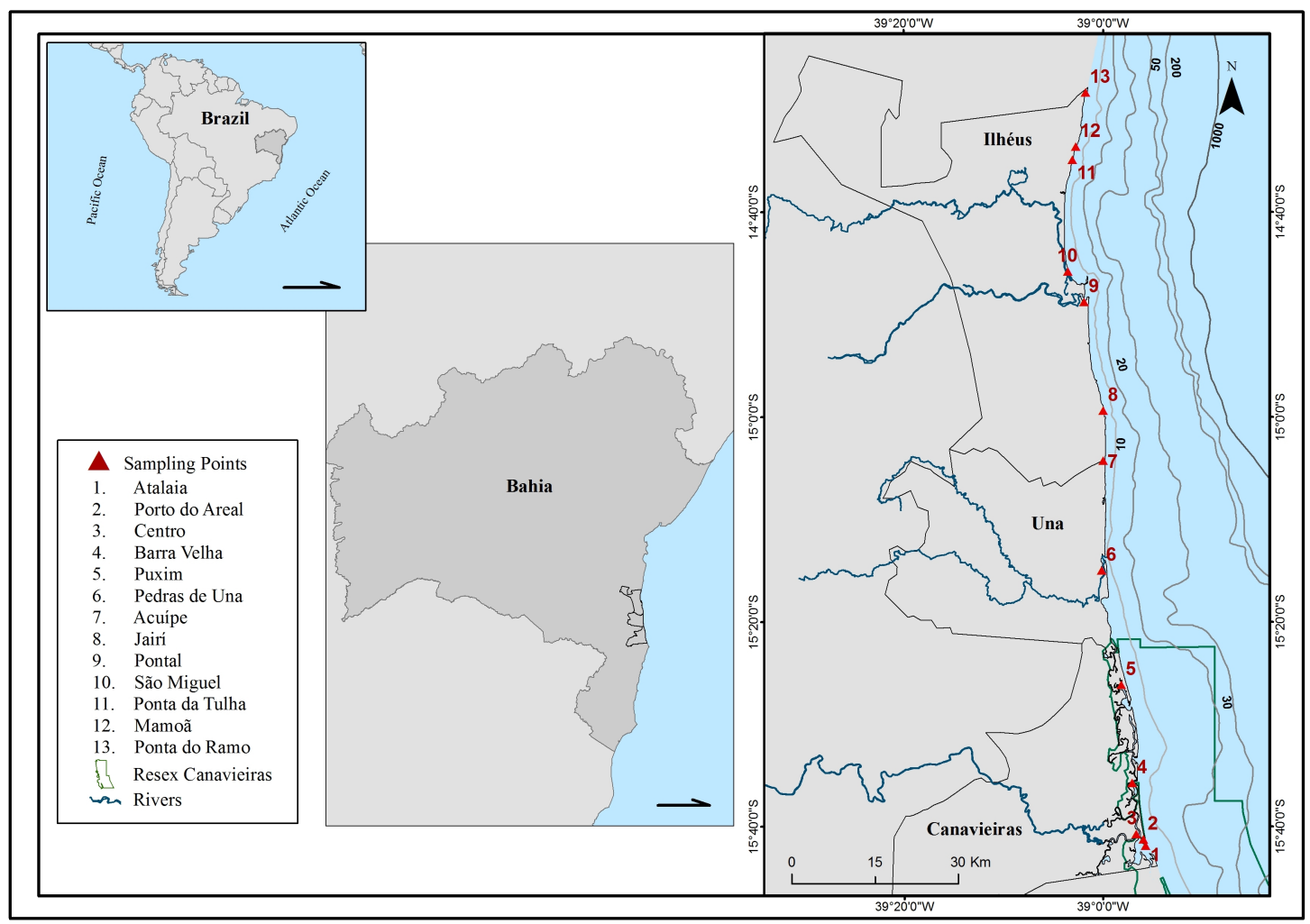

Figure 1. Map of Bahia State, Brazil, showing the fishing communities between Ilhéus and Canavieiras from which data were obtained.

(Rafinesque, 1810)) that not occur in the Brazilian Northeast region were selected to be, although they were included in analysis to serve as a control for testing species recognition by the local fishers.

The research followed the guidelines of the Declaration of Helsinki and Tokyo for humans, was approved by the Ethic Committee for Research with Human Beings of the Universidade Estadual de Santa Cruz (CAAE 01244412.3.0000.5526) and the informed consent was obtained.

\section{Data analyses}

Data were analyzed through principles of nomenclature and classification provided in Berlin (1992). A quantitative approach was applied through analysis of relative frequency of common names to designate each target species, to evaluate the ethnotaxonomic knowledge of the fishing communities. Principal common names are conventionally defined herein as those whose frequency corresponds to $15 \%(n=10)$ of the interviews due to lack of consensus among interviewees for common names applied to different shark species. Constraints are generally related to (a) natural similarity among many species of sharks shown during collecting data, (b) excessive number of species included in the analysis, (c) historical and intermittent varia- tion of common names applied to designate the same species among the adjacent fishing communities from Bahia State (Ott 1944), and (d) difficulty in recognizing species through a single picture.

\section{RESULTS}

Sharks are identified, named, and classified in detail in the fishing communities. According to the used classification system, sharks are inserted into the ethno-semantic domain called "Peixes" (Fishes). Marine fishes are sub-classified into two major folk taxa, according to the structure of tegument: "peixes de escamas" (scaled fishes) and "peixes de couro" (leather fishes). Sharks are inserted into the second group in a category known regionally as "cação" (shark) family.

Despite grouping sharks into a single major intermediate taxon called "familia dos cações" in the ethnoclassification of the fishing communities, it was possible to verify the formation of sub-classifications from the ethno-biological level through morphological characteristics of the species. In Ilhéus, $10.8 \%$ $(n=7)$ of the fishermen reported the existence of "familia dos panã" (hammerhead family) and "familia dos bico-doce" (beak-like head family). The first subgroup comprises sharks of the genus Sphyrna whose 
species have a head representing a "chapéu" (hat) or that show "cabeça em forma de chapéu" (hat-shaped head). The second sub-group comprises sharks of the family Carcharhinidae whose species exhibit head as a "bico" (pointed head), which is a classic shape frequently associated with this group of fishes.

"Família dos cações" (shark family) is a diverse group comprising 144 specific epithets in total with a mean value of 4.8 common names for each scientific correspondent. The lexeme "cação" accompanies the ethno-specific name, for instance, "cação-gata" or "cação-viola" for referring to specific folk. However, it is standard to employ the masculine definite article " $O$ " (the) before the specific epithet even when it is a feminine noun in Portuguese such as "o gata" or "o viola".

"Família dos cações" has 22 folk species when considering a minimum of $15 \%(n=10)$ frequency of citations for a target species as principal common name. A list of target species of sharks, ethno-specific principal names, and number and frequency of principal common names are provided in Table 1 . The sequence of species in Table 1 corresponds to the sequence of photographs shown to the interviewees.

Galeorhinus galeus and Carcharias taurus were not recognized by the fishermen. A model of ethnobiological classification for "Família dos cações" is proposed herein by applying Venn's diagram (Figure 2).

Besides hierarchical classification of sharks, the fishing communities group them by adopting a sequential model based on ethno-ontogeny and ethnodimorphism. Different specific epithets were employed to designate the same species when considering various stages in the life cycle of these fishes. For instance, adult Carcharhinus leucas is known as "cação-sucurupóia" and neonates as "caçãosucurupóia-galha-preta". Nomenclatural variation was also verified in a more general perspective, with different names being applied to sharks according to their life stage regardless of species. Thus, subsequent classification based on life cycle stage is observed for elasmobranch fishes, including "lambinga", "caçonete", "cação" and "tubarão". For $36.0 \%$ $(n=24)$ of the interviewees, neonates are known as "lambingas" and have "imbigo aberto" which means an open umbilical cleft. "Caçonetes" are juvenile sharks for $63.1 \%(n=41)$ of the fishermen. "Late juveniles are "caçonete", right?" says R., 60 years old. "Caçonete" is used by $29.2 \%(n=19)$ of the fishermen for adult specimens of species that reach five $\mathrm{kg}$ of maximum weight. Local fishing communities also often employ "cação" or "cação grande" (big shark) for specimens weighing more than $500 \mathrm{~kg}$. The term "tubarão" (shark) is applied when a fisherman tells a story reported in the media showing sharks interact- ing with humans, or when a local community refers to large size specimens that are caught by the fishermen.

Elasmobranch fishes are also classified according to ethno-dimorphic characteristic. Fishermen can make sexual distinction among specimens by the presence or lack of "esporões" (claspers). "Two "esporão" are present in "cação" while "caçoa" is "flat", says M. 43 years old. "Caçoa" is employed to designate female specimens using the ethno-dimorphic criteria for this lexeme.

Interviewees considered 15 criteria for naming different folk species of sharks (Table 2). However, it was noticed that these criteria are much more detailed than those shown in the photographs. For instance, the epithet "cação-de-choque" refers to the particular physiological characteristic of Narcine brasiliensis, a species that produces electrical discharges. These results reveal that conspicuous characteristics that are considered for terminology in the fishing communities often addressed a few or at least a single species. Thus, these particular characters were not initially considered as criteria for naming ethnospecies.

Difficulties in monitoring shark landings at speciesspecific level are revealed in the control system of fish landing of the Fishermen and Aquaculture Community Z-34 in Ilhéus, which is the only control system available among the three studied cities. Members of this Community emphasized some duty limitations in the identification process based on catch data for landing logbooks (e.g. caught species, weight and price). For example, overworked employees that have other job duties in the community make identification of sharks using limited and inadequate equipment, and thus it contributes towards reducing their ability to make accurate identification of species. These limitations, along with intrinsic phenotypic similarity among shark species in the region, contribute to the exclusive assignment of the epithet "cação" to designate all landed species.

\section{DISCUSSION}

Ethno-taxonomic degree of identification, classification and nomenclature of sharks in fishing communities of South Bahia, Brazil, is related to a variety of locally employed models for species classification. According to the principles of hierarchical classification proposed by Berlin (1992), the ethno-semantic domain "Fishes" corresponds to the ethno-taxonomic Life Form level in the model of classification of these fishing communities and "scale fishes" and "leather fishes" are domains that coincide to the ethno-taxonomic Intermediate level. "Família dos cações" represents the Generic level, according to Berlin (1992). Individuals may use classification systems that are overlapping and independent from one another in certain hu- 


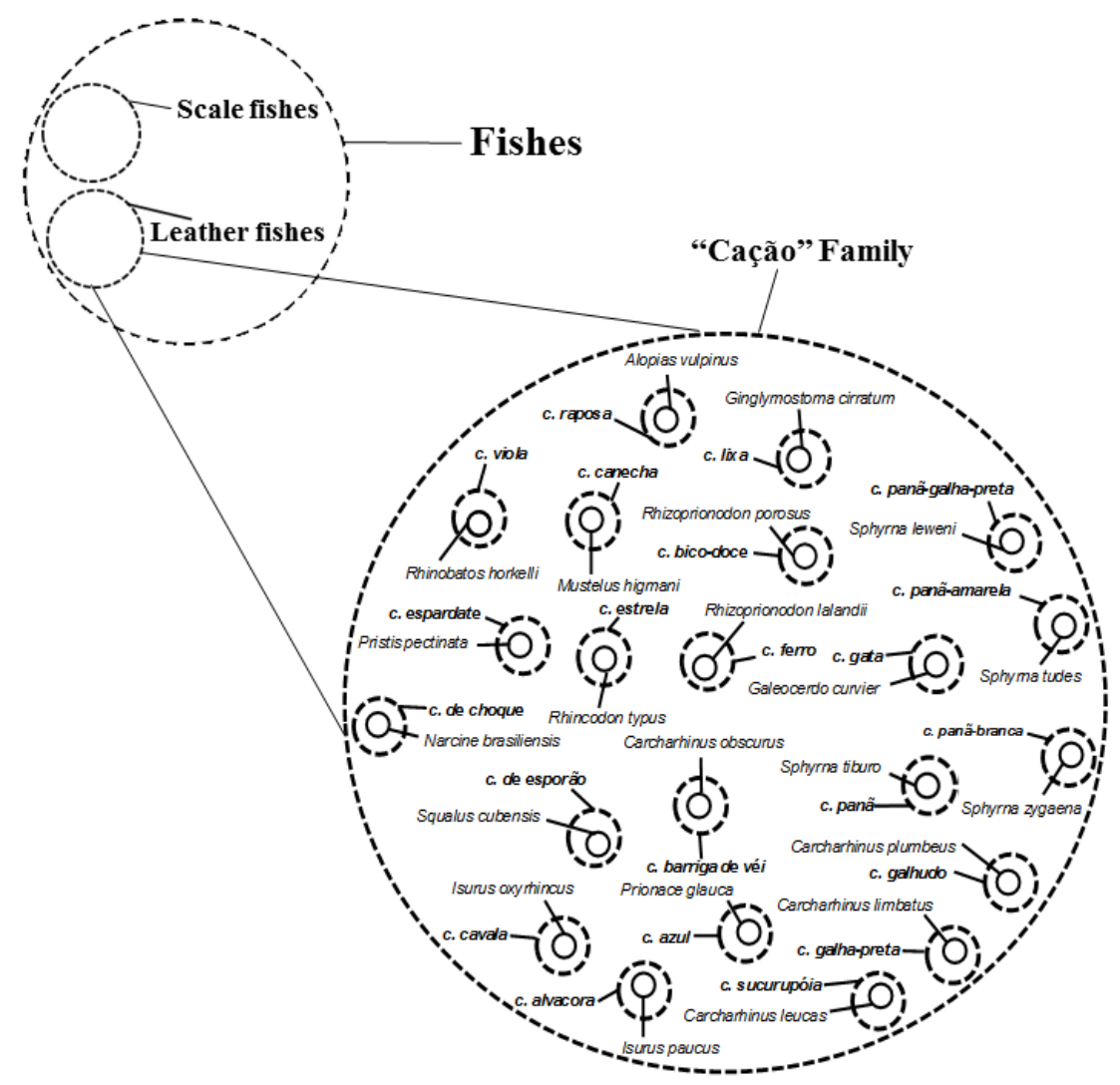

Figure 2. Diagram representing the hierarchical categories in the ethno-biological classification of "Familia dos cações", according to the fishing communities from South Bahia, Brazil.

man cultures. These ethno-biological classifications are called multidimensional classifications. Individuals use different taxonomic criteria at the stage of categorizing biotic elements of the ecosystem in this classification (Santos-Fita and Costa-Neto 2009), which explains why some fishermen consider subcategories in the "familia dos cações", including: "família dos panã" and "família dos bico-doce". Morphological criteria (e.g. head shape) were used for subdivision in this case.

The generic taxon "cação" is polytypic and reveals high diversity. Mourão and Nordi (2002) stated that the occurrence of polytypic taxa might be related to the biological diversity in some regions. Mourão and Montenegro (2006) emphasized that generic and polytypic taxa represent categories with more economic, cultural and psychological importance within specific groups. The abundance of specifics within the generic "cação" indicates the great socio-cultural relevance of sharks in the local fishing communities. Comparative analysis of the folk and scientific classification systems revealed that the generic "cação" shows the correspondence called sub differentiation of type 2 . A single generic folk taxon refers to two or more species from more than one scientific genus in this correspondence
(Berlin 1973). However, Seixas and Begossi (2001) reported that the generic "cação" includes scientific species from more than one family for the coast of São Paulo State, and these authors further highlighted the rarity of this situation.

A high degree of polysemy and synonymy is observed in the studied area, which occurs when different common names are applied to the same specific folk within the studied group. A mean value of 4.8 common names per shark species is observed, representing a value higher than that observed in Previero et al. (2013) for Corumbau Marine Extractive Reserve in South Bahia, Brazil, with a mean value of 4.0 common names per species. A mean value of 6.0 common names per species of Brazilian marine fishes was indicated in Freire and Pauly (2005), who supported that the richness of these names is related to the commercial interest of certain species. Another contributing factor to the high number of synonyms within the generic "família dos cações" is the variation of common names applied for a single shark species among different fishing communities and cities.

Implementation of a sequential model based on ethno-ontogeny of fishes was verified in many studies related to the Brazilian artisanal fishermen (Mar- 
Table 1. List of folk species of "cações" (sharks) cited in the fishing communities from South Bahia, Brazil $(n=65)$.

\begin{tabular}{|c|c|c|c|c|}
\hline Family & Taxonomic identification & Ethnospecies $(\geq 15 \%)$ & \%Citations & N Ethno-names \\
\hline Alopiidae & Alopias vulpinus & cação-raposa & 15.4 & 5 \\
\hline \multirow{17}{*}{ Carcharhinidae } & Carcharhinus acronotus & - & - & 6 \\
\hline & Carcharhinus falciformis & - & - & 8 \\
\hline & Carcharhinus leucas & cação-sucurupóia & 24.6 & 9 \\
\hline & Carcharhinus limbatus & cação-galha-preta & 93.8 & 3 \\
\hline & Carcharhinus longimanus & - & - & 6 \\
\hline & Carcharhinus obscurus & cação-barriga-de-véi & 15.4 & 8 \\
\hline & Carcharhinus porosus & - & - & 14 \\
\hline & Charcharhinus plumbeus & cação-galhudo & 15.4 & 10 \\
\hline & Galeocerdo cuvier & cação-gata & 43.1 & 10 \\
\hline & Negaprion bevirostris & - & - & 15 \\
\hline & Prionace glauca & cação-azul & 46.1 & 12 \\
\hline & Rhizoprionodon lalandii & cação-ferro & 30.8 & 7 \\
\hline & Rhizoprionodon porosus & cação bico-doce & 29.2 & 8 \\
\hline & Sphyrna lewini & cação-panã-galha-preta & 43.1 & 10 \\
\hline & Sphyrna tiburo & cação-panã & 55.4 & 13 \\
\hline & Sphyrna tudes & cação-panã-amarela & 50.8 & 11 \\
\hline & Sphyrna zygaena & cação-panã-branca & 27.7 & 11 \\
\hline Dalatiidae & Isistius brasiliensis & - & - & 6 \\
\hline Ginglymostomatidae & Ginglymostoma cirratum & cação-lixa & 90.8 & 2 \\
\hline \multirow{2}{*}{ Lamnidae } & Isurus oxyrinchus & cação-cavala & 30.8 & 5 \\
\hline & Isurus paucus & cação-alvacora & 47.7 & 7 \\
\hline Narcinidae & Narcine brasiliensis & cação-de-choque & 26.2 & 11 \\
\hline Odontaspididae & Carcharias taurus & - & - & 5 \\
\hline Pristidae & Pristis pectinata & cação-espardate & 67.7 & 6 \\
\hline Rhincodontidae & Rhincodon typus & cação-estrela & 52.3 & 10 \\
\hline Rhinobatidae & Pseudobatos percellens & cação-viola & 100 & 1 \\
\hline Squalidae & Squalus cubensis & cação-de-esporão & 46.1 & 6 \\
\hline \multirow{2}{*}{ Triakidae } & Galeorhinus galeus & - & - & 7 \\
\hline & Mustelus higmani & cação-canecha & 32.3 & 10 \\
\hline
\end{tabular}

ques 1991; Mourão and Nordi 2002). Adult specimens of Carcharhinus leucas are designated as "caçãosucurupóia" while juveniles are known as "caçãosucurupóia-galha-preta" due to ontogenetic variation in coloration. Juvenile Carcharhinus leucas shows dark dorsal fins, a pattern not observed in adults (Szpilman 2004). Differentiation between males and females within fishing communities is relevant for conservation purposes when female specimens of sharks are still alive during capture. The release of live females of threatened species comprises an essential requirement for elasmobranch conservation (Vooren and Klippel 2005).

According to Marques (1991), implementation of a variety of models of biological classification aims to arrange nature, and demonstrates a strong capacity of patterning. Mourão and Montenegro (2006) underline that a sequential system of ethnobiological classification does not deprive the Berlinean hierarchical model (Berlin 1992) as the criteria related to fish size are simply semantic and comprise an universal basis among fishing communities. Perception and recognition of biological assemblages by human beings are based on shared similarities and differences among organisms in the academic and ethno-biological classifications. Thus, the development of skills for recognition of such variability is required.

Brazil is considered a hotspot with regards to the diversity of common names employed to identify local fish species (Freire and Pauly 2003). Despite interesting cultural and linguistic aspects, such nomenclatural diversity has a negative influence on the collection of national data from fish landings, as many captured species are not accurately registered (Freire and Pauly 2003). Inadequate understanding of both popular and scientific knowledge undermines the assessment of the local fishing impact on populations of commercially important fishes (Freire and Pauly 2005). The lexeme "cação" is third in the number of homonyms and has been employed to designate 20 scientific species of five different shark families (Carcharhinidae, Lamnidae, Sphyrnidae, Squalidae, and Triakidae) (Freire and Pauly 2005). This situation restricts possible monitoring of captured species in Brazil (Freire and 
Table 2. List of classification criteria for different folk species employed by the fishermen $(n=65)$ from South Bahia, Brazil. A.f.: absolute frequency; R.f.: Relative frequency.

\begin{tabular}{lccl}
\hline \multicolumn{1}{c}{ Criteria } & A. f. & R. f. (\%) & \multicolumn{1}{c}{ Example } \\
\hline \hline Coloration & 44 & 67.7 & cação azul; cação panã-amarela; cação gata \\
Head shape & 29 & 44.6 & cação martelo; cação bico-doce \\
Fin coloration & 27 & 41.5 & cação galha-preta; cação panã-galha-preta \\
Body shape & 24 & 36.9 & cação viola; cação sucurupóia \\
Skin surface & 8 & 12.3 & cação lixa \\
Fin shape & 8 & 12.3 & - \\
Caudal fin shape & 5 & 7.7 & cação raposa; cação rabo-seco \\
Size & 5 & 7.7 & cação baleia \\
Eye length & 5 & 7.7 & - \\
Fin length & 5 & 7.7 & cação galhudo; cação ôreudo \\
Collecting site & 5 & 7.7 & cação de mangue; cação boca de barra \\
Eye color & 5 & 7.7 & - \\
Flesh color & 4 & 6.2 & - \\
Teeth absence & 2 & 3.1 & cação boca de véa \\
Behavior & 2 & 3.1 & cação sombreiro \\
\hline \hline
\end{tabular}

Pauly 2003).

To improve the collection of data at species-specific level from fish landings of exploited species in the Fishing Community Z-34 in Ilhéus, technical and financial support from public fishing organizations is necessary. Moreover, implementation of new monitoring systems of artisanal fish landings in the studied region is imperative. Trained local specialists are efficient para-taxonomists, according to Santos-Fita and Costa-Neto (2007), as they assist with efforts related to the evaluation and documentation of biological diversity. Begossi et al. (2008) emphasized that interaction between taxonomic studies and fisheries management is critical, and they further encouraged the

Table 3. Ethical perspective related to the classification criteria for different folk species in the fishing communities from South Bahia, Brazil.

\begin{tabular}{ll}
\hline \hline \multirow{2}{*}{ External characters } & \multicolumn{1}{c}{ Ethno-diagnostic characteristics } \\
\hline & - shape of specimen and specific body parts (e.g. head, caudal fin); \\
& - total length of specimen and specific body parts (e.g. head, fins, eye); \\
& - presence of "esporões" (claspers); \\
& - thickness of skin; \\
& - body coloration or color of specific body parts, such as "costas" (dorsum), \\
Morphology & "barriga" (belly), "abas" (fins), and eyes; \\
& - pattern of spots \\
& - presence/absence of teeth; \\
& - flesh color \\
Inner characters & - ability to produce an electrical discharge ("cação que dá choque"); \\
\hline Physiology & flesh consistency after capture \\
\hline Ecology & - spatial distribution in water column; \\
\hline \hline
\end{tabular}


inclusion of fishermen as para-taxonomists or paraecologists in order to propagate local conservation efforts. In the regional scenario, the employment of experienced fishermen as para-taxonomists is encouraged, using didactic identification guides of species of fishes. The fishing communities would hence be responsible for identifying elasmobranch fishes to species level.

In fact, the restriction on monitoring speciesspecific shark catches can be observed around the world, especially in developing countries (Bornatowski et al. 2014). The Convention on International Trade in Endangered Species of Wild Fauna and Flora (CITES) recognizes that the lack of taxonomists to identify the landed shark species is a challenge to the conservation of these fish and points to the need to develop friendly guides directed at non-experts and identification training for those involved in the fishery production chain (CITES 2014). The development and application of such lists have already been carried out in several regions of the world (Bonfil and Abdallah 2004; FAO 2014; FAO 2016). In addition, public training experiences have already been conducted to identify sharks. For example, several countries in the Indian Ocean, recognizing that the dificulty identifying elasmobranch species with catch restrictions, limits the possibilities of management and conservation of the group, requested FAO to carry out actions for training of fishery professionals and monitoring of shark fisheries (Bodiguel et al. 2017). Thus, between 2014 and 2016, three workshops were held in Mauritius, Seychelles and Reunion, where 150 professionals were trained in the taxonomic recognition and biological data collection of elasmobranch species captured in that region (Bodiguel et al. 2017).

Fisheries statistics depict a problematic scenario associated to the inclusion of some shark species in the official list of Brazilian aquatic threatened species, available in Portaria MMA No 445, 2014. Eight species examined in the present study are included in this list. Carcharhinus longimanus and Rhicodon typus are listed as Vulnerable. Carcharhinus obscurus is considered Endangered, and Carcharias taurus, Galeorhinus galeus, Sphyrna lewini, Sphyrna tudes and Sphyrna zygaena are listed as Critically Endangered. Any analysis associating the nomenclature of sharks from fishing communities and local fishery statistics is of great importance for management purposes or restrictions related to the exploited species. Contributions from fishing communities will be invaluable and appreciated in initiatives of this kind. spective, sharks are identified, classified and named in detail, although a variety of models of classification are employed. Richness of names to designate different folk species may hinder collection of speciesspecific information about shark landings in the region if this knowledge is not properly applied for the improvement of catch data. The name "cação" is used in the control system of fisheries landings by the Fishing and Aquaculture Community Z-34 in Ilhéus, as well as in previous Brazilian programs of fishery statistics. These results support that the identification of species is insufficient, indicating that the insertion of the ethno-taxonomic knowledge is a means to improve the fishery statistics. Thus, it will further contribute to promoting conservation actions in a more participative manner for those shark species caught in developing countries.

\section{ACKNOWLEDGEMENT}

The authors thank the Postgraduate program in Zoology (UESC) for the academic support and Coordenação de Aperfeiçoamento de Pessoal de Nível Super (CAPES) for the financial support to the Ciências do Mar project. Special thanks to the local fishermen for participating in this study and the Z-34' Fishermen Colony employees. The first author was funded by Conselho Nacional de Desenvolvimento Científico e Tecnológico (CNPQ, 132919/2011-7). We would like to thank the following authors for their permission to use or make available their species photos on the FishBase platform: John E. Randall (Photo 1, 5, 6, 9, 11, 12, 22, 25, 29), Trevor Meyer (2, 3), Daniel Villarreal (4), Alfredo Carvalho Filho (7, 28), Stephan Moldzio (8), Brandi Noble (10, 15), Hugo Bornatowski (13), Santiago Montealegre Quijano (14), Andy Murch (16, 26), Alessandro de Maddalena (17), Otto B. F. Gadig (18), Thorke A. S. Østergaard (19), Food and Agriculture Organization $(20,30)$, Cláudio L. S. Sampaio $(21,27)$, Robie Cadda (23).

\section{DATA AVAILABILITY}

The data used to support the findings of this research is available from the corresponding author upon reasonable request.

\section{CONFLICT OF INTEREST}

The author has no conflicts of interest to declare.

\section{CONCLUSION}

Fisher knowledge is refined and consistent with scientific knowledge. Under an ethno-taxonomic per- 


\section{CONTRIBUTION STATEMENT}

Conceived of the idea: MLVBF, EMCN

Data analysis: MLVBF, MR

Wrote the first draft of the manuscript: MLVBF

Wrote the Final versions of the manuscript: MLVBF, MR, JSM, RSR, RRNA, EMCN

Supervision: MLVBF, EMCN

\section{REFERENCES}

Albuquerque UP, Lucena RFP, Alencar NL (2014) Selection of Research Participants. In: Albuquerque UP, Cunha LVFC, Lucena RFP, Alves RRN (eds) Methods and Techniques in Ethnobiology and Ethnoecology. 1 ed. Springer Protocols Handbooks, New York, pp.1-13.

Atran S (1990) Cognitive foundations of natural history. Behavioral Brain Science. 21(4):547-569.

Atran S (1998) Folk biology and the anthropology of science: cognitive universals and cultural particulars. Behavioral Brain Science. 21:547-609.

Barbosa-Filho MLV, Costa-Neto EMC, Siciliano S (2017) Knowledge and practices of expert fishermen of South Bahia, Brazil, Regarding the International Shark Fin Market. Human Ecology. 44:1-9.

Barbosa-Filho MLV, Schiavetti A, Alarcon DT, CostaNeto EMC (2014) 'Shark is the man!': ethnoknowledge of Brazil's South Bahia fishermen regarding shark behaviors. Journal of Ethnobiology and Ethnomedicine. 10:54.

Beaudreau AH, Levin PS, Norman KC (2011) Using folk taxonomies to understand stakeholder perceptions for species conservation. Conservation Letters. 4:451-463.

Begossi A, Clauzet M, Figueiredo JL, Garuana LRV, Lima PF, Maccord PF, Ramires M, Silva AL, Silvano RAM (2008) Are biological species and higherranking categories real? Fish folk taxonomy on Brazil's Atlantic Forest and in the Amazon. Current Anthropology. 49(2):1-16.

Berlin, B (1973) Folk systematic in relation to biological classification and nomenclature. Annual Review of Ecology and Systematics. 4:259-271.

Berlin B, Breedlove DE, Raven PH (1973) General principles of classification and nomenclature in folk biology. American Journal Anthropology. $75: 214-242$.
Berlin B (1992) Ethnobiological classification: principles of categorization of plants and animals in traditional societies. 1 ed. Princeton University Press, Princenton, UK.

Bizzarro JJ, Smith WD, Márquez-Farías JF, Tyminski J, Hueter RE (2009) Temporal variation in the artisanal elasmobranch fishery of Sonora, Mexico. Fisheries Research. 97:103-117.

Bodiguel C, Clerkin P, Ebert DA, Wallemacq F (2017) Report of the Workshops on Identification of Pelagic Sharks and Rays in the Western Indian Ocean Report/Rapport: SFFAO/2013/34. Food and Agriculture Organization of the United Nations, SmartFish Programme of the Indian Ocean Commission, Ebène, Mauritius.

Bonfil R, Abdallah M (2004) Field identification guide to the sharks and rays of the Red Sea and Gulf of Aden. FAO Species Identification Guide for Fishery Purposes. Rome: Food and Agriculture Organization of the United Nations, Rome, Italy.

Bornatowski H, Braga RR, Vitule JRS (2014) Threats to sharks in a developing country: The need for effective and simple conservation measures. Natureza e Conservação. 12(1):11-18.

Brandão JM (1964) Glossário de nomes dos peixes; inglês, sistemático, português. Boletim de Estatística da Pesca da Sudene. 4(5):7-59.

Castello L, Castello JP, Hall CAS (2007) Problemas en el estudio y manejo de pesquerías tropicales. Gaceta Ecologíca. 84: 65-73.

CITES (2014) Xiamen Declaration \& Action Plan for the Implementation of CITES Requirements in Relation to Sharks and Manta Rays. Xiamen: Convention on International Trade in Endangered Species of Wild Fauna and Flora. 1 ed. Xiamen, Fujian, China.

Compagno LJV (2005) Checklist of living Chondrichthyes. In: Hamlett WC (ed) Reproductive biology and phylogeny of Chondrichthyes: sharks, rays and chimaeras. 1 ed. Science Publishers, Connecticut, pp.503-548.

Conklin HC (1962) Lexicographical Treatment of Folk Taxonomies. International Journal of American Linguistic. 28:119-141.

Costello C, Ovando D, Hilborn R, Gains SD, Deschenes O, Lester SE (2012) Status and solutions for the world's unassessed fisheries. Science. 338:517-520.

Dutra GF, Allen G, Werner TB, McKenna SA (2005) $A$ rapid marine biodiversity assessment of the 
Abrolhos Bank, Bahia, Brazil. 1 ed. Conservation International, Rio de Janeiro, RJ, Brazil.

Ellen RF (1993) The cultural relations of classification: an analysis of Nuaulu animal categories from central Seram. 1 ed. Cambridge University Press, Cambridge, UK.

FAO (2014) On Board Guide for the Identification of Pelagic Sharks and Rays of the Western Indian Ocean. Indian Ocean Comission, 1 ed. Food and Agriculture Organization of the United Nations, Rome, Italy.

FAO (2016) Identification guide to common sharks and rays of the Caribbean. FishFinder Programme. 1 ed. Food and Agriculture Organization of the United Nations, Rome, Italy.

Figueiredo JL (1977) Manual de Peixes Marinhos do Sudeste do Brasil. I. Introdução. Cações, raias e quimeras. 1 ed. Museu de Zoologia - USP, São Paulo, SP, Brazil.

Fischer J, Erikstein K, D'Offay B, Barone M, Guggisberg S (2012) Review of the Implementation of the International Plan of Action for the Conservation and Management of Sharks. 1 ed. Food and Agriculture Organization of the United Nations, Rome, Italy.

Freire KMF, Carvalho-Filho A (2009) Richness of common names of Brazilian reef fishes. PANAMJAS 4:96-145.

Freire K.M.F, Pauly D (2003) What's in there: common names of Brazilian marine fishes. Fisheries Centre Research Reports 11(1):1439-1444.

Freire K.M.F, Pauly D (2005) Richness of common names of Brazilian marine fishes and its effect on catch statistics. Journal of Ethnobiology 25(2):279-296.

Froese R, Pauly D (2006) FishBase: World Wide Web electronic publication [internet]. Kiel: Leibniz Institute of Marine Sciences. [http://www.fishbase.org] Accessed 02 June 2012.

Gould SJ (2001) Lance de dados: a ideia de evolução de Platão a Darwin. 1ed. Record, Rio de Janeiro, RJ, Brazil.

Humber F, Andriamahainoa ET, Berizinya T, Botosoamanantoa R, Godley BJ, Gougha C, Pedrona S, Ramaherya V, Broderick AC (2017) Assessing the small-scale shark fishery of Madagascar through community-based monitoring and knowledge. Fisheries Research 186:131-143.

Lessa R, Nóbrega MF (2000) Guia de identificação de peixes marinhos da região Nordeste. 1 ed. Programa REVIZEE/SCORE -NE - UFRPEDIMAR, Recife, PE, Brazil.

Lucifora LO, García VB, Worm B (2011) Global diversity hotspots and conservation priorities for sharks. PlosOne 6:e19356.

Maffi L (1999) Linguistic diversity. In: Posey DA (ed) Cultural and spiritual values of biodiversity. 1 ed. United Nations Environment Programme, Londres, pp. 19-58.

Marques JGW (1991) Aspectos Ecológicos dos Pescadores do Complexo Estuarino-Lagunar Mandaú-Manguaba, Alagoas. PhD Thesis, Universidade Estadual de Campinas, Campinas, BR.

Medeiros PM, Almeida ALS, Lucena RFP, Souto FJB, Albuquerque UP (2014) Use of visual stimuli in ethnobiological research. In: Albuquerque UP, Cunha LVFC, Lucena RFP, Alves RRN (ed) Methods and techniques in ethnobiology and ethnoecology. Springer Protocols Handbooks, New York, pp.87-98.

Medin DL, Atran S (2004) The native mind: biological categorization and reasoning in development and across cultures. Psychological Review 111:960-983.

Mishler BD, Donoghue JM (1982) Species concepts: a case for pluralism. Systematic Zoology. 1982; 31(4):491-503.

MMA (2002) Avaliação e ações prioritárias para a conservação da biodiversidade das zonas costeira e marinha. 1 ed. MMA/SBF Brasília, DF, Brazil.

Morril WT (1967) Ethnoichthyology of the ChaCha. Ethnology 6:405-417.

Mourão JS, Montenegro SCS (2006) Pescadores e Peixes: O conhecimento local e o uso da taxonomia folk baseado no modelo berliniano. 1 ed. Série Estudos e Debates, Recife, PE, Brazil.

Mourão JS, Nordi N (2002) Comparação entre as taxonomias folk e científica para peixes do estuário do rio Mamanguape, Paraíba - Brasil. Interciencia 27(12):664-668.

Nascimento DMC, Bittencourt ACSP, Santos NA, Dominguez JML (2007) Deriva Litorânea ao Longo da Costa do Cacau, Bahia: Repercussões na Geomorfologia Costeira. Revista Pesquisas em Geociências. 34:45-56.

Nunan GW, Senna MLV (2007) Tubarões (Selachii) coletados pelo navio oceanográfico Thalassa sobre a plataforma externa e talude continental do Brasil entre $11^{\circ}$ e $\mathbf{2 2}^{\circ}$ S. In: Costa PAS, Olavo G, Martins AS (eds) Biodiversidade da fauna marinha 
profunda na costa central brasileira. 1 ed. Museu Nacional, Rio de Janeiro, pp.163-183.

Olavo G, Costa PAS, Martins AS (2005) Prospecção de grandes peixes pelágicos na região central da ZEE brasileira entre o Rio Real-BA e o Cabo de São Tomé-RJ. In: Costa PAS, Martins AS, Olavo G (eds) Pesca e potenciais de exploração de recursos vivos na região central da Zona Econômica Exclusiva brasileira. 1 ed. Museu Nacional, Rio de Janeiro, pp.167-202.

Ott CF (1944) Os elementos culturais da pescaria baiana. Boletim do Museu Nacional. 4:1-67.

Powers SPFJ Fodrie SB, Scyphers JM, Drymon RL, Shipp RL, Stunz W (2013) Gulf-wide decreases in the size of large coastal sharks documented by generations of fishermen. Marine and Coastal Fisheries: Dynamics, Management, and Ecosystem Science 5(5):93-102.

Previero M, Minte-Vera CV, Moura RL (2013) Fisheries monitoring in Babel: fish ethnotaxonomy in a hotspot of common names. Neotropical Ichthyology 11:467-476.

Queiroz EL, Rebouças SC (1995) Tubarão - Quem tu és? 1 ed. Universidade Federal da Bahia. GECET - Grupo de estudos de Cetáceos - BA, Salvador, BA, Brazil.

Raven P, Berlin B, Breedlove D (1971) The origins of taxonomy. Science. 174:1210-13.

Santos-Fita D, Costa-Neto EM (2007) As interações entre os seres humanos e os animais: a contribuição da etnozoologia. Biotemas 20(4):99-110.

Santos-Fita D, Costa-Neto EM (2009) Sistemas de clasificación etnozoológicos. In: Costa-Neto EM, Santos-Fita D, Vargas-Clavijo M (eds) Manual de Etnozoología: una guía teórico-práctica para investigar la interconexión del ser humano con los animais. 1 ed. Tundra Ediciones, Valencia, pp.67-96.

Seixas C, Begossi A (2001) Ethnozoology of caiçaras from Aventureiro, Ilha Grande. Journal of Ethnobiology 21(1):107-135.

Sparre P, Venema SC (1997) Introduction to tropical fish stock assessment. Part 1. Manual. 1 ed. FAO Fisheries Technical Paper, Rome, Italy.

Szpilman M (2004) Tubarões no Brasil: guia prático de identificação. Aqualittera Ed, Rio de Janeiro, RJ, Brazil.

Vooren CM, Klippel S (2005) Diretrizes para a conservação de espécies ameaçadas de elasmobrânquios. In: Vooren CM, Klippel S. (eds) Ações para a conservação de tubarões e raias no sul do Brasil. 1 ed. Igaré, Porto Alegre. pp.213-228.

Yaeger KG, Culver CS, Schroeter SC, Page HM (2017) Utility of a Collaborative At-Sea Sampling Program (CASP) for the California Spiny Lobster Commercial Fishery: Catch Characteristics and Implications for Management. Marine and Coastal Fisheries Dynamics, Management, and Ecosystem Science 9:190-202.

Received: 05 May 2020

Accepted: 12 August 2020 Available: 22 August 2020 